\title{
Drainage Basin of Lake Kivu in the Western Rift of East Africa and Hazards Potential
}

\author{
Kakonkwe, C. ${ }^{1,2}$, Rwabuhungu, D. E. ${ }^{1}$, Biryabarema, M. ${ }^{1}$ \\ 1. Department of Geology, College of Science and Technology, P.O. Box: 3900 Kigali, Rwanda \\ 2. Department of Earth and Environmental Sciences, Tulane University, New Orleans, LA, USA
}

Correspondence: Christian Kakonkwe, Email: kchristian@tulane.edu

\begin{abstract}
A series of ArcGIS-generated maps were applied in analysing the potential for flooding and landslide hazards within the Lake Kivu drainage basin. This study was carried out using digital elevation data of the basin. The Kivu drainage basin encompasses an area of 7,382 $\mathrm{km} 2$. Sediment and water supply to Lake Kivu originate mostly from its eastern hinterland. The distribution of land sliding potentiality in the drainage basin shows that the northern and the southern portions of the basin are the ones with relatively low risk of land sliding, whereas the rift shoulders are most prone to land sliding. Mass wasting on slopes has the potential to grade downstream into debris and mudflows, promoting in turn further erosion and flooding.
\end{abstract}

Keywords: drainage, Kivu, Africa, flooding, landslide, hazard

\section{Introduction}

Lake Kivu, located along the western branch of the East African rift (western rift), has the highest elevation of all the Great Lakes of East Africa (Figure 1). It is situated in the central part of the western rift, considering the northeastern/southwestern axis, with a surface area of 2,728 $\mathrm{km}^{2}$ and a catchment of 7,382 $\mathrm{km}^{2}$. It is shared between the Democratic Republic of Congo (D.R. Congo) and the Republic of Rwanda. Positioned at $1461 \mathrm{~m}$ above sea level, Lake Kivu is bordered by uplifted rift shoulders to the west and east (Figure 2 and 3). The lake is in the axial zone of the rift that borders Rwanda and the D.R. Congo. In this region, the rift axis is oriented NNE-SSW. The East African rift is characterized by topographic doming and rift shoulder uplift. Morley et al. (1999) reports at least two wavelengths of doming superposed in East Africa. Topographic uplift redirects some drainage routes away from the rift lakes and rejuvenates others making them more erosive. The latter induces natural geohazards related to topography like landslides and flooding.

The objective of this paper was to look at the influence that rift topography has on the occurrence of floods and landslides in the drainage basin of Lake Kivu. A Digital Elevation Model, 1 arcsecond cell size, was used to analyse the topography of the area surrounding Lake Kivu (the Kivu dome), with a focus on the drainage basin of the lake (Figure 2). Maps showing the distribution of landslide hazards in the drainage basin of the lake are presented (Figure 6). These maps can be used by policymakers in the D.R. Congo and Rwanda as tools for informed planning in the context of natural hazards mitigation around the Lake. All maps presented in this paper were made completely digitally using ArcGIS 10.6, and Google Earth Pro. 
Both the eastern and western shoulders of the Kivu rift are uplifted (Figure 3). A dense drainage network feeds the lake in water and sediment (Figure 4). The drainage basin of Lake Kivu contains some relatively well-integrated sub-watersheds, which are more developed on the eastern margin of the lake (Figure 5). The areas, with lower elevation, close to the shoreline of Lake Kivu, are the most exposed to lake water flooding. Whereas, at the same time, they are less likely to experience land sliding compared to the highlands (Figure 6). However, they are prone to be flooded with debris flows and mudflows from the highlands (adjacent shoulders).

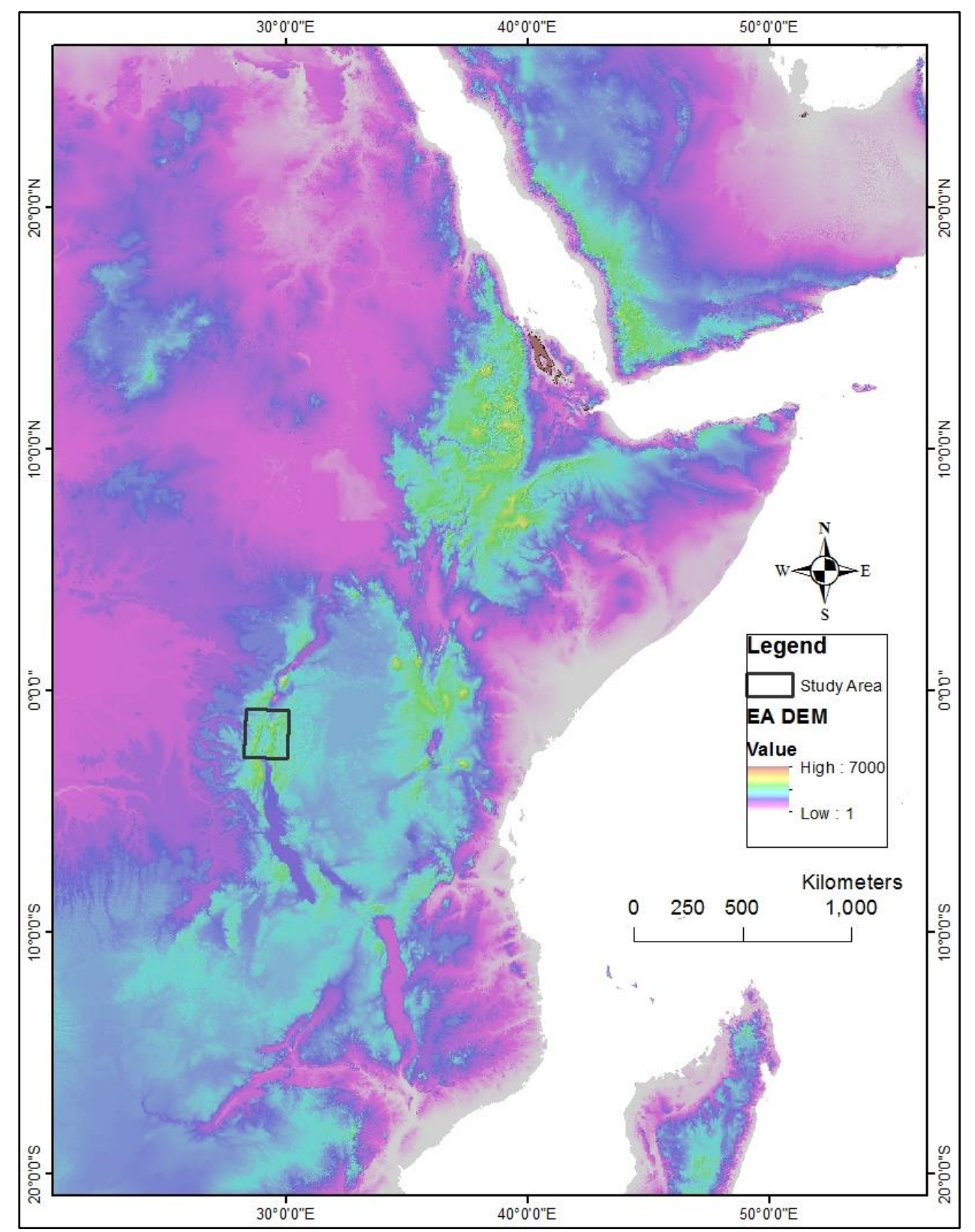

Figure 1: Shaded Relief Topography of East Africa indicating the Location of Lake Kivu (Black Rectangle in the Middle) 


\section{Background on the Characte ristics of the Kivu Basin}

The Lake Kivu rift is located along the western branch of the East African Rift system, between Lake Edward to the north and Lake Tanganyika to the south (Ebinger, 1989). The Lake Kivu basin is made up of two asymmetrical half-grabens separated by Idjwi Island (Wood et al., 2017). The half-grabens are bounded by east-dipping normal faults that accommodate tectonic subsidence. The eastern half-graben, located in Rwanda, has recently been studied by mediumdepth seismic reflection data (Wood, 2014). The western half-graben located in D.R. Congo is much less known. The rocks of the underlying basement and its margins belong to the Mesoproterozoic Karagwe-Ankole orogenic belt that extends from the Kivu-Maniema region in eastern D.R. Congo to Burundi, Rwanda, and southern Uganda (Fernandez-Alonso et al., 2012). Rifting in the Kivu region has uplifted the land in the form of the Kivu dome (part of the larger East African dome) and rift shoulders (Morley, 1999). This exposes the area to landslides and other mass wasting hazards.

A magmatic system is coupled to Lake Kivu at both ends with the active Virunga volcanic province to its north and the relatively calm South Kivu volcanic province (Pouclet et al., 2016). This active magmatic system contributes solutes and heat to Lake Kivu deep waters in the form of hydrothermal springs (Degens et al., 1973). Salts input to Lake Kivu bottom waters is what maintains its meromictic character (Damas, 1937; Schmid et al., 2005). It has been suggested that Lake Kivu originated from the buildup of the Virunga volcanic complex in Late Pleistocene (Damas, 1937; Beadle, 1981; Ross, 2014). Beadle (1981) suggested that the lake waters used to flow northwards to Lake Edward. However, Wood and Scholz (2016) proposed that Lake Kivu likely underfilled its basin for some time and that "at $\sim 12.2 \mathrm{ka}$ a change to wetter climate conditions rapidly filled the lake to spill out of the Bukavu Bay basin southward toward Lake Tanganyika." Wood and Scholz (2016) further propose that the Lake Kivu shoreline is not fixed over time but fluctuates depending on water supply.

Vast amounts of carbon dioxide and methane gases are accumulated in layers within the deep waters of Lake Kivu. Pasche et al. (2011) suggested that the carbon dioxide is of magmatic origin whereas $\sim 65 \%$ of the $\mathrm{CH}_{4}$ originates either from bacteria-mediated reduction of geogenic $\mathrm{CO}_{2}$ or from direct inflows of geogenic $\mathrm{CH}_{4}$. It is much more difficult to determine the source of the remaining methane, but it is likely organic. It is possible that part of the $\mathrm{CH}_{4}$ in Lake Kivu deep waters is sourced from the sediment column (Schmid et al., 2005), probably through a thermal maturation process or from bacterial degradation of organic matter. In any case, the presence of methane and carbon dioxide gases in the Lake Kivu deep waters poses a serious hazard potential with the risk of an uncontrolled gas eruption to the surface.

\section{Material and Methods}

The maps presented in this paper are based on analyses of Shuttle Radar Topography Mission (SRTM) Digital Elevation Models (DEM) of 1 arc-second cell size. The analyses were carried out with the assistance of the ArcGIS 10.6 software. All the DEMs were retrieved from the 
United States Geological Survey Earth Explorer website in late 2018. The maps describe the drainage basin of Lake Kivu and the distribution of flooding and landslide potentiality around the lake.

Shaded relief topography was made using the Spatial Analyst toolbox in ArcGIS 10.6 from the digital elevation model with a $\mathrm{z}$ factor (unit conversion factor from meter to degree) of $8.99 \times 10$ 6. The shoreline of the lake was mapped in Google Earth Pro. The drainage divide of Lake Kivu was mapped in ArcGIS 10.6 by editing the boundary between sub-watersheds flowing into the lake (i.e., belonging to the watershed of Lake Kivu) and those flowing away. Hydrological analyses were operated with the Hydrology toolbox in ArcGIS 10.6. The sub-watersheds of the Lake were determined from a void-filled DEM using the D8 method (Greenlee, 1987) by forcing all edge cells in the filled DEM to flow outward. The D8 method models flow direction from each cell in the raster to its steepest downslope neighbour. From the flow direction raster, the sub-watersheds were extracted, and only those covering at least 100 cells (or $\sim 95000 \mathrm{~m}^{2}$ ) were kept focusing on the large patterns. Below that limit, watersheds are too small to be mapped clearly. Knowing the watersheds that supply Lake Kivu and their neighbours flowing away (from our stream network data), the boundary was mapped as Lake Kivu drainage divide, commonly known as the "Congo-Nile divide" in Rwanda.

To extract the stream network of the Lake Kivu drainage basin from the filled DEM, a flow accumulation raster in ArcGIS 10.6 that uses the flow direction raster as input was first calculated by counting the number of cells that flow into every individual cell from its upstream. A conditional statement was applied on the flow accumulation raster such that every cell with upstream cells flowing into it greater than or equal to 1054 be assigned a value of 1 , all other cells having a no data value. The result was the stream raster. The value 1054 represents the number of cells covering an area of $1 \mathrm{~km}^{2}$. It was assumed that a minimum of $1 \mathrm{~km}^{2}$ drainage is required for headwaters to initiate from precipitation around Lake Kivu. The stream network shapefile was then generated from the stream raster, considering flow direction. The thus generated stream network was superposed on the DEM, and it was observed that they match (streams are along with areas of relatively low elevation).

The landslide potentiality mapping in the drainage basin of Lake Kivu was also based on DEM analysis. In this paper, we define land sliding potentiality (Ps) based on the topography as the product of normalized slope( $\mathrm{S} / 90)$ and normalized elevation (Z/Zmax).

$$
\text { Ps }=\frac{S . Z}{90 . Z \max }
$$

Where $\mathrm{S}$ is the slope of the raster cell and $\mathrm{Z}$ its elevation; $\mathrm{Zmax}$ being the maximum elevation of the study area, and 90 the maximum slope possible. Normalizing means that a cell of slope 90 has a potentiality of 1 to slide under gravity when located at the maximum elevation of the area. Likewise, a cell at maximum elevation has a potentiality of 1 to slide under gravity when it has a slope of 90 . Potentiality varies from 0 to 1 . Note that this method considers slope and elevation 
only as factors of land sliding. Other conditions like lithology and structure, regolith thickness and shear strength, rainfall, land use, vegetation cover, etc. influence land sliding potentiality.

\section{Results}

The amount of topographic uplift of the rift shoulders in the eastern and western lake margins varies (Figure 3). Along the western margin of the lake (in D.R. Congo), elevation of the rift shoulder is above $2500 \mathrm{~m}$ (Figure $3 \mathrm{~A}, \mathrm{~B}$, and C), whereas along the eastern margin (in Rwanda) elevation varies from nearly same level with that of the western margin to the north (Fig. 3A) to $2000 \mathrm{~m}$ in the central part (Kibuye) (Figure $3 \mathrm{~B}$ ), rising again to $2500 \mathrm{~m}$ in the southern (Nyamasheke) part (Figure $3 \mathrm{C}$ ). Secondly, the eastern shoulder of the Lake Kivu rift has a much larger wavelength as compared to the western shoulder.

The variation in the topography of Lake Kivu's margins determines the lake's drainage area differences in the western margin compared to the eastern margin. The relatively steep and prominent fault line scarp to the west, showing relatively less slope retreat, accounts for the relatively narrow catchment on the western margin. A relatively broader catchment characterizes the eastern margin. A less prominent fault line scarp has led to extended in-land erosion by incoming rivers and subsequently a more substantial slope retreat.

Most of the precipitation on the rift shoulders flows in the opposite direction of the lake given the narrow drainage basin. The drainage divide (Figure 2 and 4) of Lake Kivu passes along the summits of three volcanoes: Nyamuragira, Nyiragongo, and Karisimbi, located north of the lake. Rift shoulder uplift resulted in the reversal of some drainage on the two margins of the lake. It is observed that to the north and south of the lake, streams flow in the lake direction, with no sign of drainage reversal (more on this in the Discussion and Conclusions). Lake Kivu has a dense drainage network, with a catchment area of $7382 \mathrm{~km}^{2}$. Additionally, it is observed (Figure 5) that the sub-watersheds within the drainage basin have different degrees of development when comparing the eastern (Rwanda) to the western (D.R. Congo) margins of the lake. Subwatersheds are larger (more developed) on the eastern margin compared to the smaller, numerous sub-watersheds on the western margin of Lake Kivu. There is a match between the drainage network generated numerically and the DEM, in terms of drainage lying along valleys as exemplified by the Kibuye sub-watershed (Figure 7).

This study investigated landslide potentiality caused by topography (elevation and terrain slope) alone (Figure 6). It can be observed that, based on slope gradients and elevation, a large part of the watershed is prone to land sliding, other factors remaining favourable. Only areas at an elevation close to lake level and with negligible slopes can be considered relatively safe from land sliding. However, most of those areas are also the ones that are most exposed to lake flooding. Under the tropical climate of the Lake Kivu area, steep slopes combined with much rain, easily erodible regolith, and less land cover would trigger landslides translating into debris flows and mudflows. 


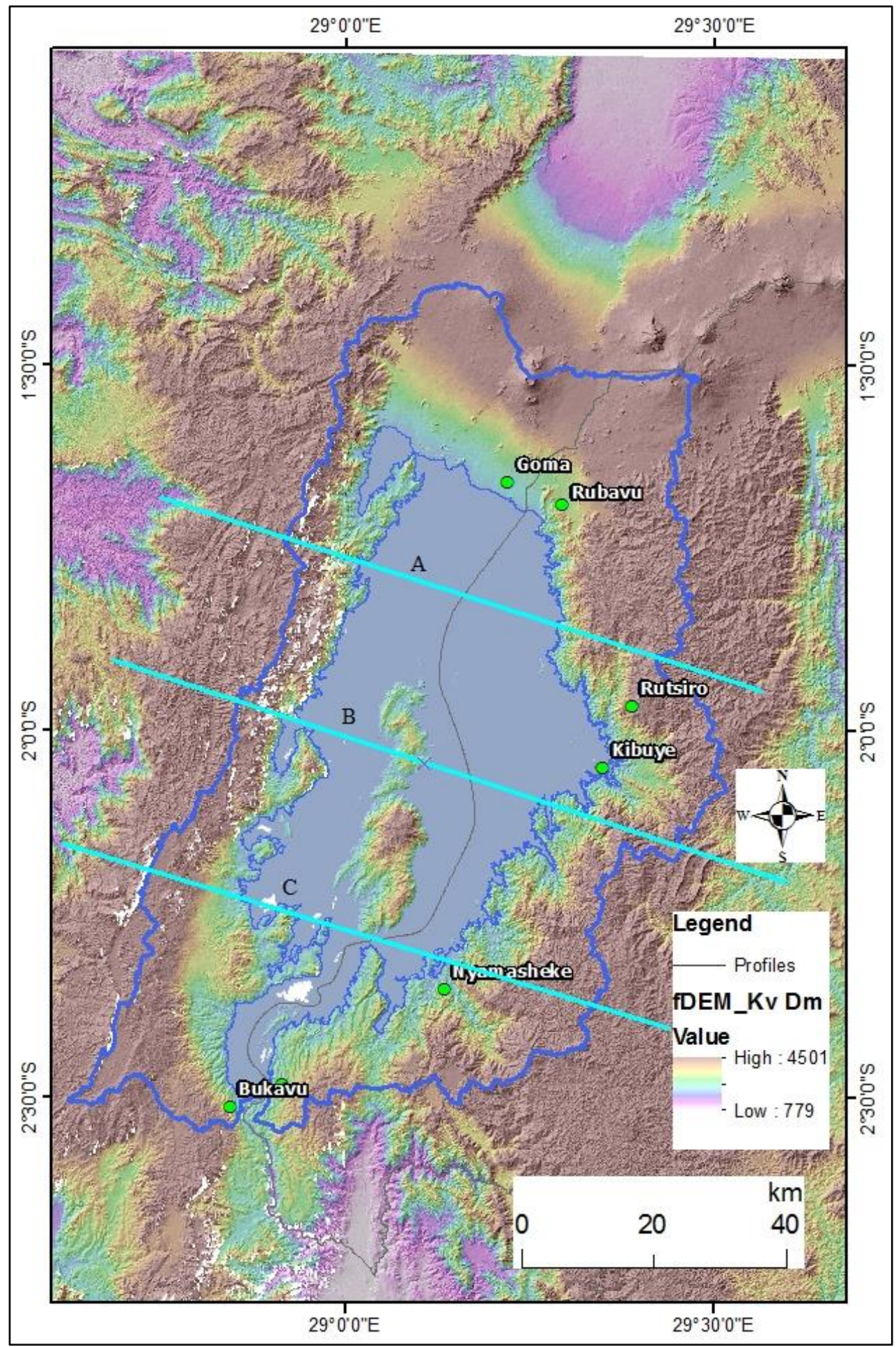

Figure 2. Relief topography of Lake Kivu and its surroundings; showing the drainage divide of the lake and locating the profiles shown in the previous Figure 3. 


\section{Topography of the Northern Kivu Rift Segment}

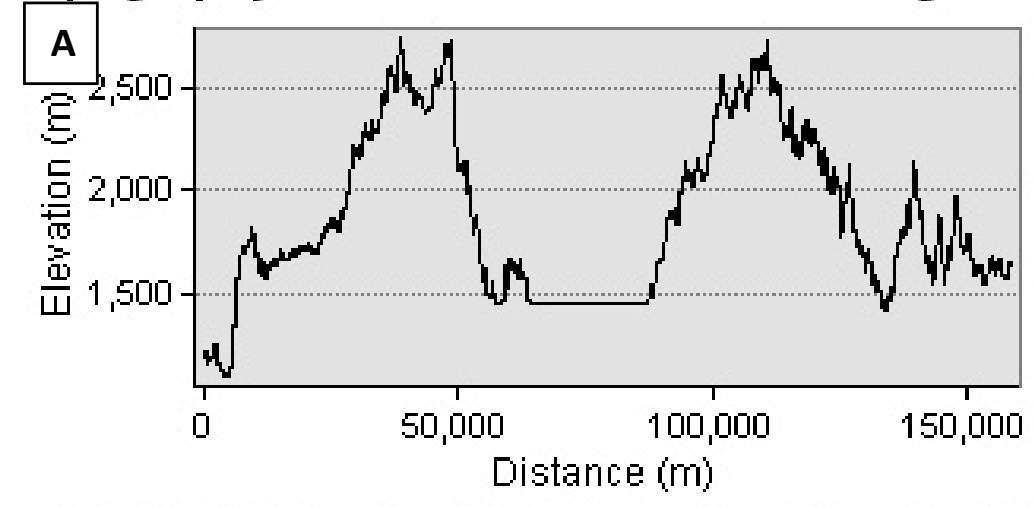

WWW to ESE: rift fiank and border fault; Lake; rift flank (fault?)

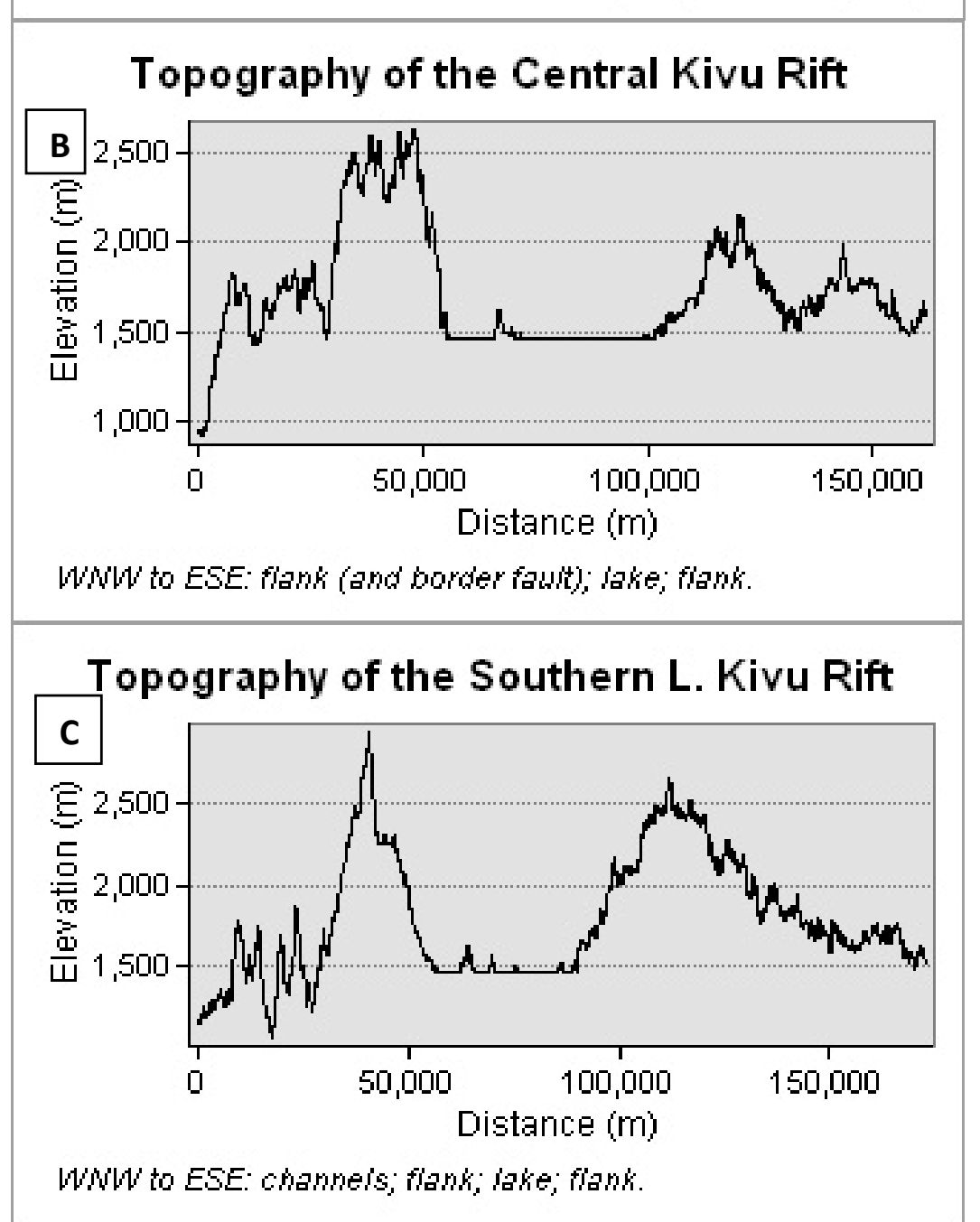

Figure 3. Topographic profiles across Lake Kivu, showing the rift lake and its uplifted shoulders 


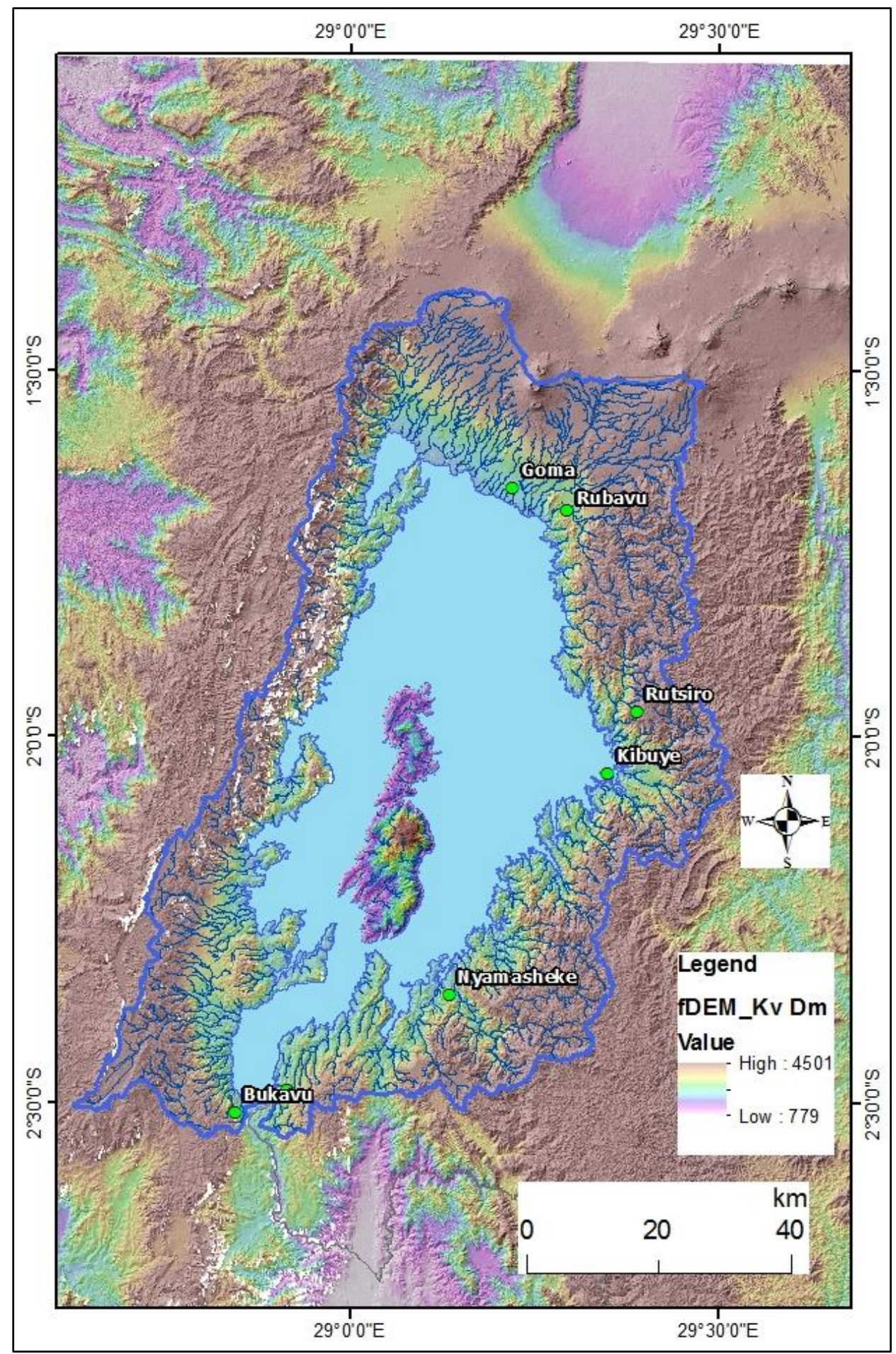

Figure 4: Lake Kivu Watershed and Drainage Pattern (Streams represented as Blue Lines) 


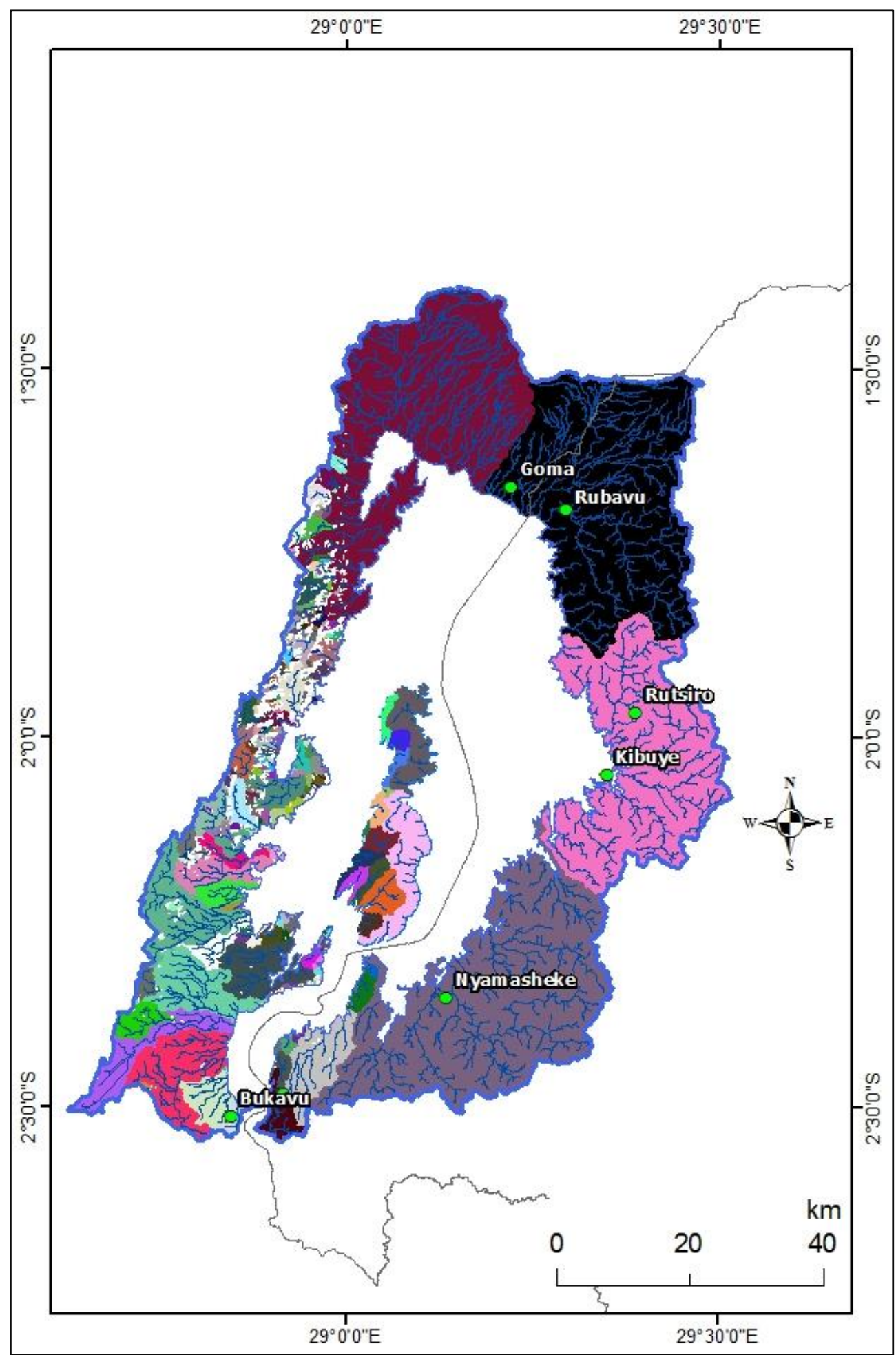

Figure 5. Sub-watersheds and Drainage Pattern in the Drainage Basin of Lake Kivu. 


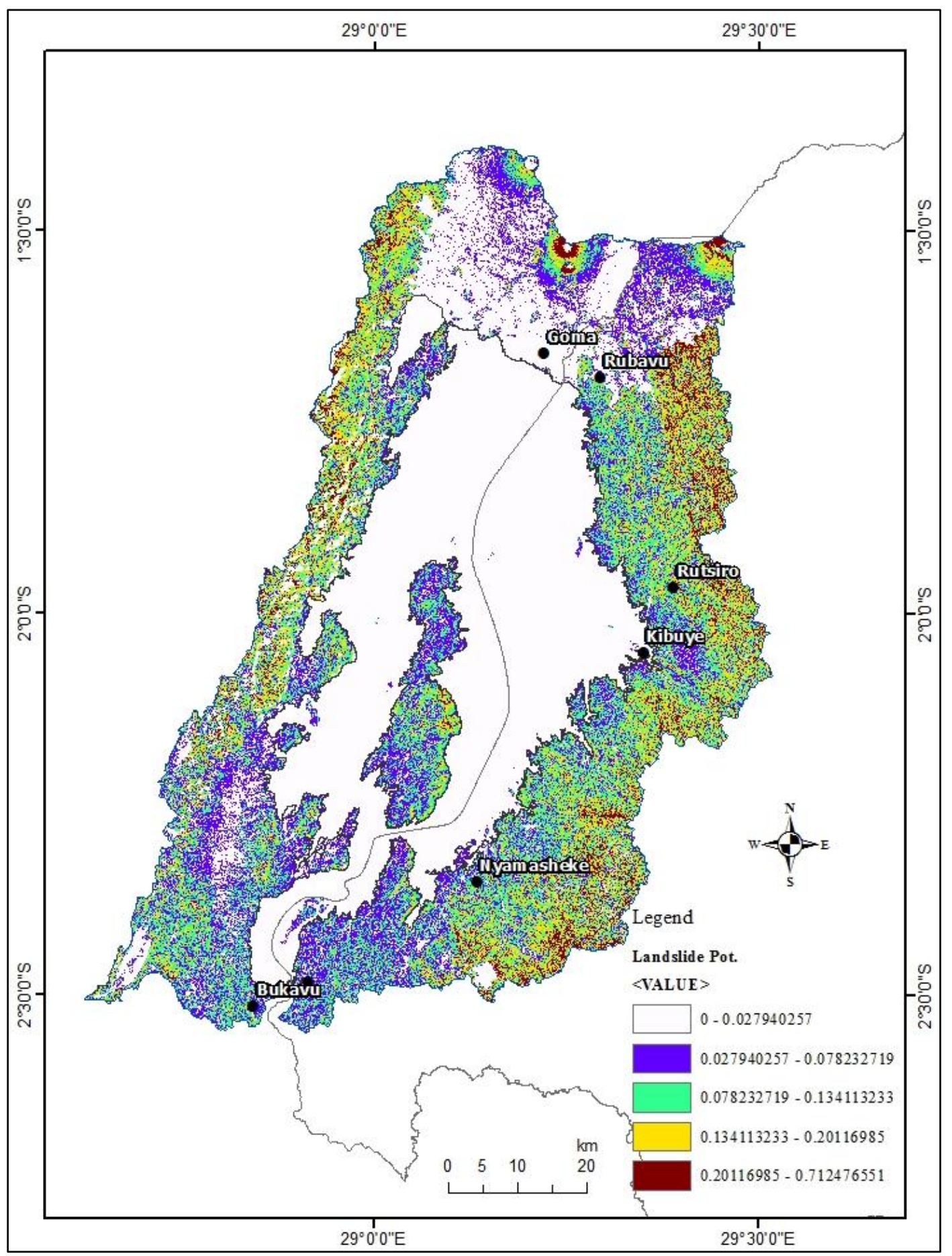

Figure 6: Distribution of Landslide Generation Potentiality in the Watershed of Lake Kivu based on Elevation and Slope Gradient. Potentiality Varies on a Scale of 0 for No Landslide Risk to 1 for Maximum Landslide Hazard Potential 


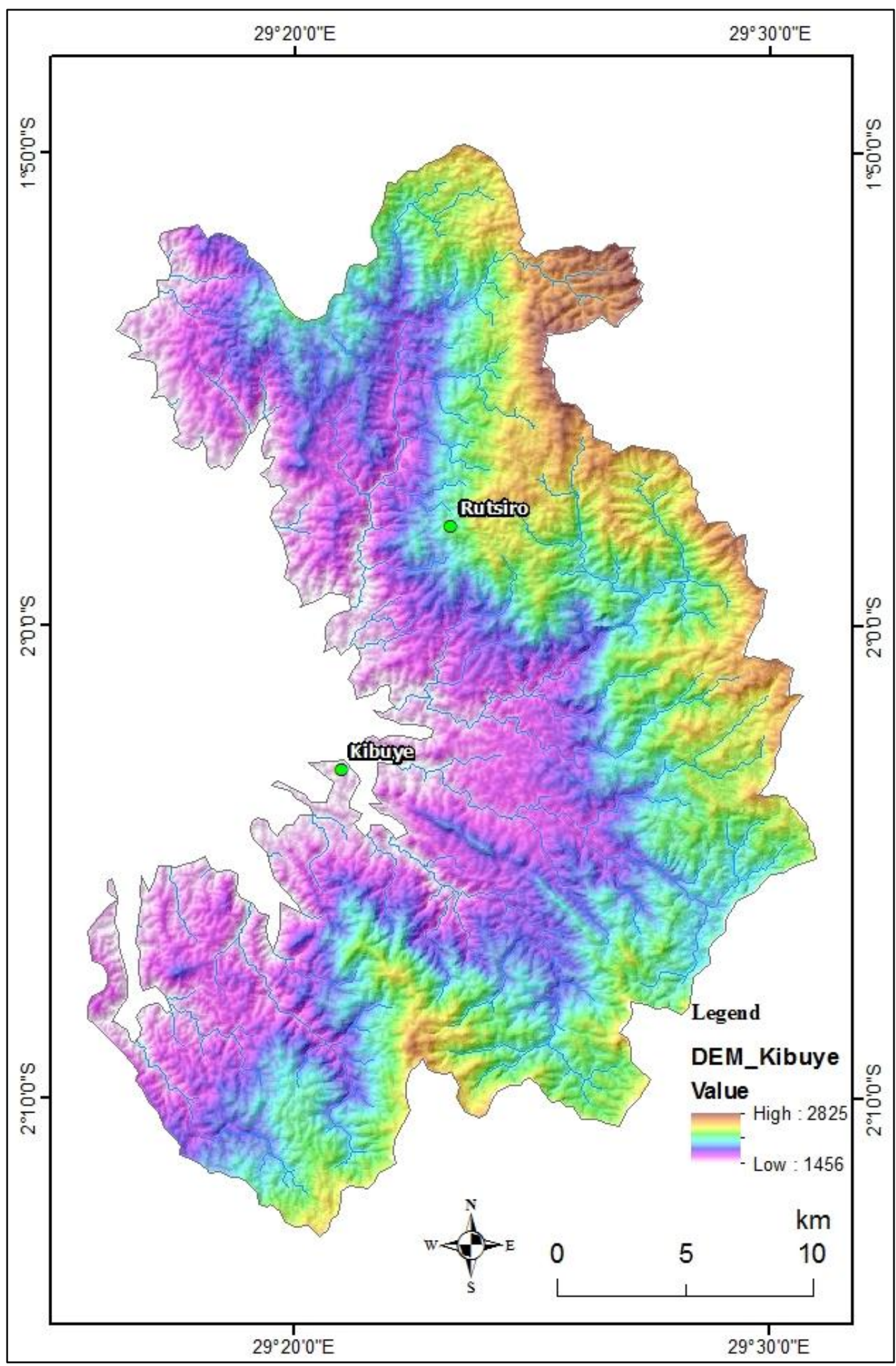

Figure 7. Sub-watershed around Kibuye, Rwanda, along the Eastern Margin of Lake Kivu on Digital Elevation Model. Drainage Network displayed as Blue Line 


\section{Discussion and Conclusions}

Rift shoulder uplift redirects most of the drainage away from the basin lying in the axial zone of the rift. Nevertheless, the uplifted rift shoulders remain the major sources of terrigenous sediment to Lake Kivu. The lake drains a smaller area on its western margin compared to the eastern, suggesting that the eastern margin probably supplies more sediment and water to Lake Kivu.

While some reversal of drainage pattern affects the two shoulders of Lake Kivu, none is noted north of the lake. Signs of drainage reversal are likely buried under the lavas of the Virunga complex. The authors of this paper do not exclude the option that Lake Kivu probably did not drain northward as that would have required overfilling of the lake basin before the built-up of the Virunga complex (Wood and Scholz, 2016). We recommend geological/geomorphological field investigations north of Lake Kivu to confirm whether signs of lake overfilling not noted in seismic data exist. This study aligns with the idea that Lake Kivu filled its basin at about 12 ka as demonstrated by Wood (2014) and Wood and Scholz (2016) and has subsequently been draining southwards since overfilling its basin. Geomorphological evidence is still lacking to support whether the lake used to drain northward to Lake Edward (Beadle, 1981).

The drainage basin of Lake Kivu is subject to potential flooding and landslide hazards. The distribution of land sliding potentiality as defined in this paper (Figure 6) shows that areas immediately close to the lake, and the south and north of it in general have the lowest land sliding potentiality. Land sliding is also coupled with debris and mudflows in rainy seasons. The drainage routes north of Lake Kivu can be used to predict future flow routes for Virunga lava (with special attention to the active Nyiragongo and Nyamuragira volcanoes). Future work should involve field investigations to (1) tie the digitally generated drainage patterns to field streams and rivers and (2) tie the landslide potentiality mapping to field sub-watersheds and landslide occurrence. The maps presented in this paper can be used by government agencies for the prevention and mitigation of natural geohazards.

\section{Acknowledgment}

We thank the University of Rwanda for support for our research. The United States Geological Survey is thanked for providing the digital elevation data used in the preparation of this paper. Alabi A. Amos and Martins A. Onimisi of the University of Rwanda, and Douglas A. Wood of the U.S. NOAA are thanked for discussions that helped to develop this paper. Comments from anonymous reviewers helped improve the quality of the manuscript.

\section{References}

Beadle, L.C. 1981. The inland waters of tropical Africa: an introduction to tropical limnology, 2nd edn. Longman, London

Damas, H., 1937. Quelques caractères écologiques de trois lacs équatoriaux : Kivu, Edouard, Ndalaga. Ann Soc Roy Zool Bel 68: 121-135 
Degens, E.T., Kulbicki, G., 1973. Hydrothermal Origin of Metals in Some East African Rift Lakes. Mineral. Deposita (Bed.) 8, 388-404

Ebinger, C.J., 1989. Tectonic development of the western branch of the East African rift system. Geological Society of America Bulletin, v. 101, p. 885-903

Fernandez-Alonso, M., Cutten, H., De Waele, B., Tack, L., Tahona, A., Baudet, D., Barritt, S.D., 2012. The Mesoproterozoic Karagwe-Ankole Belt (formerly the NE Kibara Belt): The result of prolonged extensional intracratonic basin development punctuated by two short-lived far-field compressional events. Precambrian Research 216-219, 63- 86

Greenlee, D. D., 1987. Raster and Vector Processing for Scanned Linework. Photogrammetric Engineering and Remote Sensing 53 (10): 1383-1387.

Morley, C.K., Ngenoh, D.K., and Ego, J.K., 1999. Introduction to the East African Rift System, in C.K. Morley ed., Geoscience of Rift Systems-Evolution of East Africa: AAPG Studies in Geology No. 44, p. 1-18.

Pasche, N., Schmid, M., Vazquez, F., Schubert, C.J., Wüest, A, Kessler, J.D., Pack, M.A., Reeburgh, W.S., and Bürgmann, H., 2011. Methane sources and sinks in Lake Kivu, J. Geophys. Res., 116, G03006, doi:10.1029/2011JG001690.

Pouclet, A., Bellon, H., Bram, K., 2016. The Cenozoic volcanism in the Kivu rift: Assessment of the tectonic setting, geochemistry, and geochronology of the volcanic activity in the South-Kivu and Virunga regions. Journal of African Earth Sciences, Elsevier, 121, pp.219-246. $<10.1016 /$ j.jafrearsci.2016.05.026>. <insu-01330382>.

Ross, K.A., Smets, B., De Batist, M., Hilbe, M., Schmid, M., Anselmetti, F.S., 2014. Lake-level rise in the late Pleistocene and active subaquatic volcanism since the Holocene in Lake Kivu, East African Rift. Geomorphology 221, 274-285

Schmid, M., M. Halbwachs, B. Wehrli, A. Wüest (2005), Weak mixing in Lake Kivu: New insights indicate increasing risk of uncontrolled gas eruption, Geochem. Geophys. Geosyst., 6, Q07009, doi:10.1029/2004GC000892.

Wood, D.A., 2014. Structure, paleolimnology and basin history of the East Kivu Graben, Lake Kivu, Rwanda from offshore seismic reflection data. MS thesis, Syracuse University

Wood D.A., Scholz C.A., 2016. Stratigraphic framework and lake level history of Lake Kivu, East African Rift. Journal of African Earth Sciences xxx 1-13

Wood, D.A, Zal, H.J., Scholz, C.A., Ebinger, C.J., and Nizere, I., 2017. Evolution of the Kivu Rift, East Africa: interplay among tectonics, sedimentation, and magmatism. Basin Research 29 (Suppl. 1), 175-188, doi: 10.1111/bre.12143 